Article

\title{
Daoism and the Project of an Ecological Civilization or Shengtai Wenming 生态文明
}

\author{
Martin Schönfeld ${ }^{1, *}$ and Xia Chen ${ }^{2}$ \\ 1 Department of Philosophy and College of Global Sustainability, University of South Florida, Tampa, \\ FL 33620, USA \\ 2 Chinese Academy of Social Sciences, Beijing 100732, China; chenxiaxiao2713@sina.com \\ * Correspondence: mschonfe@usf.edu
}

Received: 20 September 2019; Accepted: 29 October 2019; Published: 14 November 2019

\begin{abstract}
For China today, environmentalism is central. The socialist doctrine of "Xi Jinping Thought" prioritizes transitioning to sustainability in the goal of building an "Ecological Civilization". This creates unprecedented opportunities for Daoist practitioners to engage in state-coordinated activism (part 1). We show how the science of the planetary crisis (part 2) resonates with Daoist values (part 3), how these values integrate in national policy goals (part 4), and how this religious environmental activism plays out in case studies (part 5).
\end{abstract}

Keywords: religious environmental activism; China; Taoism; sustainability

\section{Introduction}

Daoism is often described in Philosophy as the greenest of all schools of wisdom, and in Religious Studies as the faith that puts nature's Way, the Dao 道, at the center of reverence. ${ }^{1}$ This understanding, while essentially correct, needs to be reconsidered for three reasons. One is that the crossing of planetary thresholds has altered the meaning of 'nature' and 'green'. Another is that China has gone through profound changes since the Cultural Revolution, which affect Daoism and environmentalism alike. A third is that, in the 21st century, Daoist practitioners are working with the Communist Party to turn the People's Republic of China into a sustainable and post-carbon society.

During the Cultural Revolution, religions were suppressed and their practitioners persecuted. Environmentalism was condemned as a reactionary attitude according to Stalinist doctrine. After Mao's death in 1976, repression eased and Daoism was rehabilitated. Mao's successor Deng Xiaoping 邓小平 initiated a course correction in the 1980s that realigned Chinese socialism with Leninist doctrine, not only with Lenin's New Economic Policy, but also with Lenin's advocacy of environmental activism (Foster 1999; Vogel 2011). ${ }^{2}$ Deng's successor Jiang Zemin 江泽民 implemented this realignment in the 1990s and called for a balance of economic growth and environmental protection. In 2007, Jiang's successor Hu Jintao 胡锦涛 expanded this call into the vision of an Ecological Civilization (shengtai wenming 生态文明).

1 We would like to thank Leslie Sponsel (University of Hawaii), Jau-wei Dan 但昭偉 (University of Taipei), James Miller (Duke University-Kunshan), and three blind reviewers for their helpful comments on revising this manuscript.

2 For the difference in Soviet thought between Lenin and Stalin over ecological issues, cf. (Foster 1999, pp. 392, 394). Foster points out that Lenin promoted conservationism, established nature preserves, and implemented environmental policies during the New Economic Policy period (NEP, 1921-1928), whereas Stalin's "disconnection of Soviet thought from ecological issues, from the 1930s on, was severe" (p. 394). China's course change follows these lines-while Mao Zedong embraced Stalinist doctrine, Deng Xiaoping returned to Leninist ideas by appropriating the NEP doctrine as China's post-Maoist 'state capitalism' and by initiating a government reversal over environmental policy. For Deng Xiaoping's embrace of Leninist environmental policy and his promotion of reforestation, cf. (Vogel 2011, pp. 712-13). 
For China's 21st century iteration of Marxism-Leninism, environmentalism is central. In 2017, Xi Jinping 习近平, president since 2013, elevated Hu's vision to a policy and decreed the construction of an Ecological Civilization as a priority. In contrast to Maoism, today's socialist doctrine, "Socialism with Chinese Characteristics for the New Era" (xin shidai zhongguo tese shehui zhuyi 新时代中国特色 社会主义), also known as “Xi-Jinping Thought” (xi jinping sixiang 习近平思想), is a future-oriented outlook that grounds policy in science and draws from China's legacy of philosophical and religious traditions. This ideological sea change has created unprecedented opportunities for Daoist practitioners to engage in environmental activism, coordinated by the Communist Party towards the construction of an ecological civilization.

China's environmental course-correction is neither sheer idealism nor a propaganda ploy. Instead, it is a pragmatic response to deteriorating environmental conditions and consequent public protests. "Growing societal pressure has vaulted environmental protection to the top of the Chinese leadership's agenda" (Economy 2018). ${ }^{3}$ Tolerance for religions such as Daoism under these conditions is also born out of necessity. The shift from a Stalinist command economy under Mao to Leninist state capitalism under Deng implied a partial retreat of the government from the society. This was not only a retreat from the market but also from other roles formerly performed exclusively by the state, such as providing social welfare and health care. Nonstate actors have filled the void. Xi has reversed this trend and once more extends the reach of the state. But his politburo also accommodates itself to the post-Maoist reality of nonstate actors in China. Recruiting these actors for the efforts of stabilizing the environment and mitigating climate change is an efficient strategy for the Communist Party to delegate work that needs to get done, and it constitutes an opportunity for nonstate actors such as the Chinese Daoist Association, est. 1957 (CDA, zhongguo daojiaoxiehui 中国道教协会), to practice what they preach.

The consequence of the Party's accommodation to organized religion is a de-facto alliance of Daoism and Communism. ${ }^{4}$ The Party coordinates the activism of practitioners into regional projects, and the greening of socialism empowers the CDA to be an agent in the sustainability transition. Xi's pursuit of an ecological socialism has effectively enlisted Daoism in China's fight against climate change. Ironically, this turns the Daoist tenet of following nature's Way into an implicit aspiration of Xi Jinping Thought.

We will examine Daoist environmental activism in light of China's project of an Ecological Civilization with several case studies. Because of the shifting meanings of environmentalism, and its political ascendancy in China, we will put Daoist environmental activism both in scientific perspective and in a political context. The subject of Section 1 is the contemporary transformation of the environment, mirrored in a more complex meaning of environmentalism. Section 2 consists of an examination of the green elements in Daoist spirituality vis-à-vis this transformation, and how the transformation lends these elements explanatory and predictive power. The subject of Section 3 is China's aspiration to an Ecological Civilization, and its implications for a new model of development. Section 4 consists of case studies in several Chinese provinces that illustrate what environmental activism by Daoist practitioners means in the planetary emergency.

3 (Economy 2018, p. 14).

4 This alliance is historically a step beyond the integration of the Chinese Daoist Association in the socialist state. The CDA was founded in 1957 as a "national patriotic religious group" (aiguo zhongjiao tuanti) (爱国宗教团体). Its founding document calls on all Daoists "to protect ... and support the socialist construction of the motherland ... under the leadership of the people's government" (aihuo zuguo ... bing zai renmin zhengfu lingdao xia, ... qiwei zhichi zuguo de shehui zhuyi jianshe 爱护祖 国 ... 并在人民政府领导下 ... 起为支持祖国的社会主义建设). The CDA was suppressed during the Cultural Revolution 1966-1976. Under the Deng administration, the CDA was rehabilitated to its former status in 1978. The Jiang administration reaffirmed the party's policy of religious freedom while also seeking to guide religion to adapt to the socialist society in 1993. While Deng regarded religions as neutral, Jiang declared them to be “positive forces" (jiji liliang 积极力量) for building socialism with Chinese characteristics. 


\section{The Shifting Conception of Environmental Activism}

The new global reality can be summed up in civilization being on a collision course with the boundaries of the Earth System (Wackernagel et al. 2002). ${ }^{5}$ Several planetary boundaries have been overshot, and two of them are of particular significance: the capacity of the carbon cycle in the climate system, and the speciation-extinction balance in the biosphere. Breaking through the carbon boundary has caused climate change, and overshooting the biodiversity boundary has unleashed a global extinction event.

In the climate system, the collision course of human growth with the carbon boundary has accelerated global warming. The acceleration is amplified in the Arctic. Climate change in the north polar region is forty years ahead of predicted scenarios, and the Greenland melt-off is now four times as fast as had been modeled (Bevis et al. 2019; Box 2019; Fettweis et al. 2013; Fettweis 2019; Hayhoe et al. 2017). ${ }^{6}$ Human emissions of $\mathrm{CO}_{2}$ and $\mathrm{CH}_{4}$ (methane) are overwhelming the assimilative capacity of the carbon cycle, resulting in rising greenhouse gas concentrations and mean surface temperatures. The results are visible in the acidification of the oceans, the increase in extreme weather events, and the intensification of heatwaves.

In the biosphere, the human collision course with the speciation boundary has led to what is now recognized as the sixth mass extinction in the history of life. The scale of this event comes into view when considering the extent of contemporary land conversion. In 2019, humanity exploits $72 \%$ of the planetary surface (Intergovernmental Panel on Climate Change IPCC). ${ }^{7}$ Today, $96 \%$ of all mammals are humans and livestock, and 70\% of all birds are chicken and poultry (Fletcher 2019; Bar-On et al. 2018). ${ }^{8}$ In the 20th century, before the extinction unfolded in earnest, conservationism involved saving endangered species and protecting biological diversity. But now, biodiversity loss is joined by defaunation: a thinning of common species (Dirzo et al. 2014)..$^{9}$ (Biodiversity loss is counted in species; defaunation is counted in populations.) The combination of biodiversity loss and defaunation reveals the size of the extinction: since 1970, vertebrates (i.e., mammals, birds, reptiles, amphibia, and fish) have declined by $60 \%$ worldwide and by $90 \%$ in the tropics (Díaz et al. 2019; Grooten and Almond 2018). ${ }^{10}$ As the earlier collapse of bee colonies shows, invertebrates have not been spared either (Engelsdorp et al. 2007, 2008; Neilson 2019). ${ }^{11}$ Since 1990, flying insects have declined by $75 \%-80 \%$ in some northern countries,

5 The Earth System is the biophysical whole constituted by the interactions of biosphere, hydrosphere, cryosphere, lithosphere, and atmosphere. It is a complex system of the critical biophysical processes, cycles, and services that sustain life on Earth. In (Wackernagel et al. 2002), M. Wackernagel et al. write (p. 9266), "Sustainability requires living within the regenerative capacity of the biosphere ... [but] human demand may well have exceeded he biosphere's regenerative capacity since the 1980 s ... humanity's load corresponded to 70\% of the capacity of the global biosphere in 1961 and grew to 120\% in 1999".

6 The situation in the Arctic has outpaced worst-case models. Here are details for the interested reader. For a 2019 update, cf. (Bevis et al. 2019). For a mid-2019 update from Arctic measuring stations, cf. (Box 2019). For the mid-2019 ablation rate [= net mass of ice lost from land as meltwater pouring into the ocean], cf. (Fettweis 2019). The acronyms in (Fettweis 2019) are as follows: $\mathrm{MAR}=$ mean annual runoff; $\mathrm{SMB}=$ surface mass balance; $\mathrm{GT} / \mathrm{Day}=$ gigatons per day. Fettweis (ibid.) states that he is 'using SSP585.' This refers to the SSP 5-8.5, which is the coupled climate model that links the shared socio-economic pathway (SSP) 5, the worst-case model for civilization, of continued "fossil-fueled development," with the representative concentration pathway (RCP) 8.5, the worst-case model for global climate, in which radiative forcing reaches greater than 8.5 watt per $\mathrm{m}^{2}$ by 2100 , corresponding "to a future where carbon dioxide and methane emissions continue to rise as a result of fossil fuel use;" cf. (Hayhoe et al. 2017). For an earlier model of Greenland's melt-off, which underscores how the 2019 situation has escalated, cf. (Fettweis et al. 2013). For a non-technical summary, cf. (Holthaus 2019). For an editorial based on the mid-2019 Greenland weather station tweets, cf. (Linden 2019).

7 For data on land conversion, cf. (Intergovernmental Panel on Climate Change IPCC). For a non-technical summary, cf. (McKie 2019).

8 For data on mammals and birds, measured in biomass, cf. (Bar-On et al. 2018); See also (Fletcher 2019, chp. 8, p. 316).

9 (Dirzo et al. 2014).

10 (Díaz et al. 2019), Background A.6, p. 13; cf. also (Grooten and Almond 2018), pp. 7-10 and chp. 3, pp. 88-107.

11 For early signs of the collapse of bee colonies, cf. (Engelsdorp et al. 2007, 2008). For the situation in 2019, cf. (Neilson 2019; Milman 2019). 
and by $90 \%-95 \%$ in some tropical territories (Hallmann et al. 2017; Vogel 2017; Jarvis 2018). ${ }^{12}$ Such declines in biota are termed 'biological annihilation' (Ceballos et al. 2017). ${ }^{13}$

Global warming and biological annihilation are linked, because climate and biosphere affect one another. Both are complex systems, and their dynamics are entangled (Ayres 2000). ${ }^{14}$ This means that destabilizing the one destabilizes the other. Global warming worsens the extinction, and the extinction worsens global warming. The link from climate to the biosphere is clear enough: plant and animal species try to adapt to rising temperatures by moving to higher latitudes or altitudes, but physical obstacles and human barriers interfere with such migrations, with the result of biota falling by the wayside.

The reverse link-from biosphere to climate-is not so obvious. At the same time, it highlights the shifting meanings of environmental concepts. The reverse link is that the extinction weakens the structural integrity of the biosphere, and that climate responds to this weakened integrity with greater sensitivity to external forcings such as carbon emissions (Steffen et al. 2015). ${ }^{15}$ The more we replace flora with crops and fauna by livestock, the less stable this dynamic becomes. The climate system is reacting more strongly than before to emissions; biodiversity loss and defaunation are making climate become 'tippy'.

To avoid pushing the climate beyond tipping points, the 2015 Paris Accord sought to limit global warming to $2{ }^{\circ} \mathrm{C}$ above the preindustrial baseline (the two-degree guardrail). Scientific findings in 2018 moved the goal posts to $1.5^{\circ} \mathrm{C}$ of warming (Steffen et al. 2018). ${ }^{16}$ Since temperatures today are $1.0^{\circ} \mathrm{C}$ higher than before the Industrial Revolution, additional global warming must be limited to $0.5^{\circ} \mathrm{C}$ to stay in the safe operating space of humankind. We have already broken through the planetary boundary of the carbon cycle, but if we also break through the $1.5^{\circ} \mathrm{C}$ guardrail, the climate will be put on a trajectory towards "Hothouse Earth" (Steffen et al. 2018). ${ }^{17}$ Positive feedback loops will kick in to fuel runaway global warming (e.g., by $\mathrm{CH}_{4}$ outgassing from melting permafrost). If that happened, matters would be out of our hands. Temperatures would then keep rising higher even if all human emissions were to cease completely.

In response to this finding, in fall 2018, the Intergovernmental Panel of Climate Change (IPCC) released a report, Global Warming at $1.5^{\circ} \mathrm{C}$ (SR15). Avoiding the hothouse fate requires a reduction of carbon emissions to $50 \%$ by 2030 and to zero by 2050 (Intergovernmental Panel on Climate Change IPCC). ${ }^{18}$ In short, humanity has ten years left to embark on worldwide decarbonization and step back from the cliff. Since civilization is meeting $85 \%$ of its energy needs with fossil fuels, with carbon emissions rising by $2 \%$ annually as recently as 2018 (British Petroleum 2019), avoiding the hothouse fate will require a revolutionary effort. ${ }^{19}$

In the past, environmental activism was motivated by aesthetic and moral considerations, about the wellbeing of planetary life, the integrity of ecosystems, and the beauty of the natural environment. Today, motivations and concerns are more complex. The hothouse fate adds an existential worry, since it would trigger civilization collapse if not averted. This complexity is reflected in new goals, such as sustainability, and new names of activist organizations, such as Extinction Rebellion. Put differently, in the past, there was a gulf between nature and culture- the natural environment and human civilization were separate phenomena in our lifeworld. Today, nature and culture have merged.

12 For the vanishing of flying insects, cf. the so-called Krefeld study that triggered the alarm: (Hallmann et al. 2017); cf. also (Vogel 2017). For a non-technical review, cf. (Jarvis 2018).

13 (Ceballos et al. 2017).

14 For a classic description of entanglement, cf. (Ayres 2000).

15 (Steffen et al. 2015), esp. pp. 6-7.

6 (Steffen et al. 2018).

7 (Steffen et al. 2018), fig. 2 "Stability Landscape".

18 (Intergovernmental Panel on Climate Change IPCC), Summary for Policymakers, section C "Emission Pathways and System Transitions consistent with $1.5^{\circ} \mathrm{C}$ Global Warming," paragraph C1, p. 15.

19 (British Petroleum 2019). For global energy demand, cf. "Shares of global energy consumption by fuel," p. 11; for growth in carbon emissions, cf. "2018 at a glance", p. 2. 
Nature merges into culture because the fate of human civilization is now tied to biosphere integrity and climate stability. Culture merges into nature because human activity is now affecting the functioning of the Earth System. This changes the meaning of being green. Before, being green was a matter of protecting beauty and doing the right thing. Now, being green has become a matter of existence, adaptation, and evolution.

\section{Daoist Environmentalism}

The ecological outlook of Daoism is well-known, and there exists considerable scholarship on the topic (Chen and Schönfeld 2013). ${ }^{20}$ The injection of existential worries into ecological concerns presents a paradigm shift for environmentalism. We argue that Daoism is well-equipped to handle this sea change. Daoism has conceptual resources for responding to the collision course with planetary boundaries, and for supplying the shifting conceptions of environmentalism with a coherent narrative. These resources allow practitioners to make sense of the new realities without having to revise their traditional doctrines.

Misconceptions of Daoism tend to arise, paradoxically, when one approaches it by seeking differentiations. Daoist concepts tend to involve continua and polarities instead of contrasts and distinctions (Moeller 2006). ${ }^{21}$ This affects even general concepts, such as 'philosophy' and 'religion,' and basic relations, such as those between facts and values in philosophy, and that of nature and God in religion. The term for 'religion,' zongjiao 宗教, was coined by foreign scholars in their study of Chinese culture; that for 'philosophy,' zhexue 哲學, was invented by Japanese scholars in their introduction of western philosophy to Japan, and Chinese scholars appropriated it for their own ends. These neologisms, while scholarly projections, reflect the distinctly Chinese approaches to wisdom and the divine. Rather than a Socratic love of wisdom, Chinese philosophy is a 'learning' ( $x u e$ 學) of 'wisdom' (zhe 哲). The idea of 'wisdom-learning' reveals a focus on answers and insights. This differs from the Socratic focus on questions and problems.

Chinese variants of religious creeds, encapsulated in the term zongjiao, denote not so much a covenant with God, but rather 'teachings' (jiao 教) of schools hailing from 'ancestors' (zong 宗). ${ }^{22}$ The words for 'God,' shangdi 上帝 (lit. “Lord on High") and tian 天 (which doubles as 'heaven'), attracted considerable interest among early modern missionaries but fall short of the Abrahamitic concept. One reason is the equivalence of 'heaven' and 'God'-instead of the former serving as the seat for the latter, the terms are coextensive, as if divinity were a field. Another is that tian denotes both 'heaven' and 'sky,' suggesting that God is in nature. To the extent shangdi means 'God,' it does so by denoting a supreme deity such as Zeus, who lords on high, but lacks the power of creation (Chan 1963; Perkins 2004). ${ }^{23}$

One implication of these conceptual continua is the absence of a demarcation between philosophy and religion. To be sure, there is a reflective, theoretical side of Daoist wisdom (daojia 道家) taught in philosophy departments, and a reverential, lived side of Daoist faith (daojiao 道教) practiced in temples. But their boundary is blurry. The ancient Daoist thinkers Laozi 老子 and Zhuangzi 子 are read and debated as one does philosophers, but they are also worshiped as deities (Kohn 2014; Miller 2017). ${ }^{24}$

20 For a select bilingual bibliography of scholarship on Daoism, cf. (Chen and Schönfeld 2013), note 1, p. 74, and references, p. 75.

21 (Moeller 2006, pp. 16-20).

22 In (Miller 2017, p. 2), J. Miller comments, "This does not mean that there was no religion in China before [the 19th century invention of zongjiao], but rather that Chinese people conceptualized the kinds of traditions and cultural complexes that we call religion differently enough to warrant the invention of a new term." For the terms daojia and daojiao—Daoist 'religion' and Daoist 'philosophy'—cf. (ibid., p. 136).

23 (Chan 1963, p. 4; Perkins 2004, p. 17).

24 For Zhuangzi's elevation to semi-immortality and assumption of a position in the celestial office of the Great Ultimate according to the revelations of the Highest Clarity school of Daoism, cf. (Kohn 2014, pp. 114-15). For Laozi's enshrinement as the 'God of Ecology' by the Chinese Daoist Association, cf. (Miller 2017, p. 5). 
Another implication is the lack of a distinction between nature and the divine. In Daoism, the transcendent is immanent; it is not relegated to a supernatural heaven but suffuses nature instead. In the School of Orthodox Unity (zhengyi dao 正一道), the prevalent form of Daoist spirituality in Taiwan, the apex of the pantheon is occupied by the Three Pure Ones (sanqing 三清). They are the manifestations of Dao: the 'non-pole' or primordial universe (wuji 無極), the 'great pole' or infinite potential (taiji 太極), and yin-yang or complementary dialectics (liangji 兩儀). These manifestations are heavens in the sense of transcendent realms-but they are also gods in the sense of personified deities. In the latter sense, wuji is the Lord of Primordial Beginning (yuanshi tianzun 元始天尊); taiji is the Lord of the Numinous Treasure (lingbao tianzun 靈寶天尊), and liangji is the Lord of Way and Virtue (daode tianzun 道德天尊). In Orthodox Unity Daoism, the Lord of Way and Virtue is the philosopher Laozi. So, instead of a distinction between heaven and Earth, there is a continuous universe both sacred and secular; instead of a distinction between heavens and gods, heavenly realms and divine spirits are coextensive properties of the Three Pure Ones; and, instead of a distinction between gods and humans, the Third Pure One, Laozi, happens to be both.

The characteristic lack of distinctions brings Daoist environmentalism into view. Nature-a peak, a creek, a seashore, a grove-is inhabited by deities, who deserve reverence, and whose dwelling-places are owed protection. The spiritual ontology of Daoism is akin to that of Buddhism and animist folk religion. This commonality allows for syncretism, such as the Chinese fusion of Daoism with animist folk religion. Practitioners are not conflicted when paying their respects to the Three Pure Ones as well as to the local Earth God (tudigong 土地公). But beyond this commonality are motifs specific to Daoism, which make its naturalistic outlook uniquely well suited to the contemporary environmental crisis. These motifs are a continuum of culture and nature, the normative character of natural facts, a soft anthropocentrism, and, as a consequence, an evolutionary conception of natural and human existence.

The first motif, the culture-nature continuum, expresses itself in the cliche of nature-worship-while the Confucian scholar applies himself in the city, the Daoist sage seeks solitude in the wilderness. Nature is the ultimate framework, integrating everything, including culture. The relevance of this Daoist continuum for environmentalism is easy to see. Overshooting the carbon balance expresses itself in rising greenhouse gas concentrations everywhere in the atmosphere. Overshooting the biodiversity balance expresses itself in the decline of wildlife everywhere on the planet. The human footprint steps on nature entire: soot from combustion is found on Antarctica; nitrogen from agricultural runoff creates dead zones in the oceans; plastic from consumer products litters remote islands. Not a single nook of wilderness remains pristine today; humanity has left its chemical, physical, and biological marks everywhere. This is an uncanny phenomenon, and some governments in the West, as those of USA, Australia, and Brazil, remain in denial of the threats implied by this new reality. Yet dissolving the distinction of culture and nature is precisely the hallmark of the Anthropocene. Since the lack of this distinction is fundamental to the teachings of Daoism, the new reality does not pose any cognitive challenges to its practitioners.

The second motif that makes it easier for Daoist practitioners to recognize the threats implied by this new reality and to act accordingly is the central precept of Daoism-to follow the Dao, which follows its own nature (dao fa ziran 道法自然):

Humans follow Earth,

Earth follows heaven,

heaven follows Dao,

and Dao follows (its own) nature. ${ }^{25}$

25 Daodejing c. 25: 人法地, 地法天, 天法道, 道法自然。 The rendition 'to follow,' as by G.-F. Feng/J. English (New York: Vintage, 1997) or by S. Addiss/S. Lombardo (Indianapolis: Hackett, 1993), is a translation of the term fa 法, lit. "law", as in "earth is the law of humans". R. T. Ames and D. L. Hall (New York: Ballantine, 2003) suggest "to emulate" instead: "Human beings emulate the earth. The earth emulates the heavens, the heavens emulate way-making, and way-making emulates 
There is a pattern of energy-flows, a way of how nature proceeds. The Daoist sage (shengren 聖 人) knows how to abide by this pattern and 'go with the flow'. In the Daodejing 道德經, this idea is expressed in the demand "to be the stream of the universe" (c. 28), for "the universe is sacred; you cannot improve it" (c. 29). ${ }^{26}$ The reason is a pragmatic concern, motivated by self-interest: "what goes against the Dao comes to an early end" (c. 30). ${ }^{27}$

Seen in this way, the climate emergency is the outcome of not following the Dao. Instead of going with nature's flow, humanity went against it and now risks coming to an early end in the hothouse fate. The sixth mass extinction is yet another consequence of going against the Dao, and it is also symptomatic of humanity dismissing Daoist values. Central to Daoist values is the rejection of destructiveness, domination, and competition. The Daodejing counsels, "Achieve results, but not through violence" (c. 30). ${ }^{28}$ The Daoist cherishes three core values or 'treasures' (san bao 三寶); they are mercy ( $c i$ 慈), frugality (jian 儉), and humility (hou 後; c. 67). The environmental crisis is the effect of disregarding these treasures: instead of mercy, civilization proceeds with a lack of empathy; instead of frugality, civilization embraces capitalism; and instead of humility, civilization indulges in hubris. Doing violence to nature shows a lack of wisdom. The Daodejing warns: "When humans lack a sense of awe, there will be disaster" (c. 72). ${ }^{29}$

Unlike religions whose practitioners indulge in climate skepticism, as the powerful Evangelical Protestant pluralities in USA, Australia, and Brazil, there is no place in Daoism for such indulgencies. Its teachings already contain explicit warnings of the new realities. Furthermore, its holy scriptures need no interpretive retrofit. Without need for exegetical modification, they can serve as spiritual framework for the challenges of the Anthropocene. Unlike Evangelicals, Daoists can simply say, we told you so.

Next to the subordination of culture to nature and the precept of following the Dao, there is a third motif, which could be called 'soft anthropocentrism'. As we have seen, the proper place of humanity is its harmonious integration in nature. Instead of dominating nature, civilization ought to aspire to a cultural paradigm of mercy, frugality, and humility. And yet, humans occupy a special place in the universe. The Classic of the Great Peace or Taipingjing 太平经, a collection of Daoist scriptures from the Han dynasty, has this to say about humans:

Humans are at the center of yin and yang, and the teachers of all things

Humans are the children of heaven and earth and the leaders of all things. ${ }^{30}$

The opening pages of the Classic of the Three Days of Interpretation or Santian Neijie Jing 三天内解经 make the same point just as forcefully:

Heaven, Earth, and humans are the three powers, and they are the ancestors of all things. ${ }^{31}$

The issue of anthropocentrism has been confounding to environmental outlooks. Major theories in environmental ethics, such as the Land Ethic and Deep Ecology, reject anthropocentrism for the sake of eco- and biocentric alternatives, and do so for a plausible reason, because environmental concerns seem to require a pivot away from human-centered interests. Current approaches in climate ethics, however, proceed from explicitly anthropocentric premises, and do so for an equally plausible reason, because climate change directly impacts human communities. Daoism avoids this conundrum and

what is spontaneously so"; cf. (ibid., p. 115). Unless indicated otherwise, my citations follow the Feng/English translation. For an analysis of verse 25, cf. (Moeller 2015).

26 Daodejing c. 28: 為天下谿. Ames and Hall, loc. cit., p. 120, suggest, “be a river gorge to the world”. Daodejing c. 29: 天下神 器, 不可為也. Ames and Hall, p. 122, suggest, "the world is a sacred vessel, and is not something that can be ruled".

27 Daodejing c. 30: 不道早已.

28 Daodejing c. 30: 果而勿强.

29 Daodejing c. 72: 民不畏威, 則大威至.

30 Taipingjing sec 644: 人者, 在阴阳之中央, 为万物之师长... 人乃天地之子, 万物之长也. cf. Wang Ming 王明, ed., Taiping Jing Hexiao 太平经合校 (Beijing: Chinese Press 中华书局, 1960). My translation.

31 San Tian Neiji Jing part 1, c. 2: 故天、地、人三才成德, 为万物之宗. My translation. 
sidesteps this dichotomy of anthropocentrism and non-anthropocentrism by choosing to sustain their contradiction. Nature's flow is the center of all things, and yet humans occupy a special place. They are equal and yet superior to their nonhuman kin-equal, in that they share needs and vulnerabilities with all living beings, and yet superior, in that they are the "leaders," (zhang 長), "teachers" (shi 師), and "ancestors" (zong 宗).

To mitigate climate change and to staunch the sixth mass extinction needs precisely the kind of ambiguity that Daoism suggests. A crisis-response requires empathy with nonhuman others, an empathy grounded in humility and in the kinship of all life. But for the response to succeed, humanity must show leadership. That is to say, the quietist approach of 20th century environmental activism, to exhort people to step aside so as to give nature space, is obsolete. We have struck the planet with a fever that requires medical attention. Climate change can be reined in only by interventions ranging from sequestration to reforestation to decarbonization. The sixth mass extinction can be stopped only by biosphere management. The leadership required from humanity is to serve as healers of the Earth System. As healers, humans would put nature's flow front and center while playing a leading-yet-serving role.

Sustaining the contradiction between equality and superiority, between humility and leadership, is a daunting task. Avoiding the hothouse fate forces humanity to assume the mantle of planetary stewardship. This has never been done before. Getting to sustainability requires an evolutionary leap for civilization. But once again, Daoism supplies the requisite spiritual narrative. The requisite narrative is both a corollary of the previous three motifs-the culture-nature continuum, following the Dao, and soft anthropocentrism - and arguably also a motif of its own: co-evolution.

The evolution of nature is part of the cosmogony and ontology of Daoism. The Daodejing speaks to nature's self-organization: Dao radiates (c. 4); it is the mother and the root of heaven and Earth (c. 6); it creates being, being yields dialectics, and dialectics spawns complexity (c. 42). ${ }^{32}$ The Zhuangzi contains an account of the evolution of life, from "seeds of things" (zhong 種) to simple beings such as “membranes" ( ji 聯) and “lichens" (wa bin zhi yi 蛙䗰之衣; lit. “the clothes of frogs and oysters"), to complex organisms such as panthers, horses, and men. ${ }^{33}$

Since nature evolves, following nature's way means humans evolve, too. The self-organization of nature suggests a progression of human development to higher stages of civilization. The Zhuangzi offers several concepts for these evolved stages—-the wise human (shengren 聖人), the ultimate human (zhiren 至人), and the divine human (shen ren 神人). ${ }^{34}$ The Daodejing contains an evocative description of a co-evolved society in the penultimate chapter (c. 80): it is a society with low population density, where humans take death seriously, store their weapons, do not use tools, and return to the old ways. In this future, humans live simple and well, and they leave each other in peace (Schönfeld 2013, 2014). ${ }^{35}$

To summarize, Daoist environmentalism proceeds from the absence of distinctions. It involves a conceptual and a spiritual side, and it merges the secular with the sacred. There are no boundaries between nature and the divine, and between humans and nature. This informs Daoist environmentalism. Nature is in a continuum with culture. Environmental facts entail norms. Humans are equal and yet superior to life on Earth. And finally, just as nature evolves, so should civilization. These motifs, in their combination, provide Daoist practitioners with a spiritual narrative that grounds environmental activism in the contemporary realities of the Anthropocene-the sphere of humans is coextensive with that of nature; planetary boundaries dictate the parameters of practice; the planetary crisis imposes the task on humans to rejoin the community of life as its stewards. Rising to the occasion is an evolutionary

\footnotetext{
Daodejing c. 4: 道; c. 6: 玄牝之门, 是谓天地根; c. 42: 道生一, 一生二, 二生三, 三生万物. My translation.

Zhuangzi, c. 18, sec. 7. cf. also (Zhuangzi 1994, pp. 172-73).

4 Zhuangzi, c. 1, sec. 3. Mair translates sheng ren as "the sage," zhi ren as "the ultimate man," and shen ren as "the spiritual person," cf. (Zhuangzi 1994, pp. 5-6).

35 Daodejing c. 80: 小国寡民。…民重死而不远徙。虽有舟舆, 无所乘之, 虽有甲兵, 无所陈之。使民复结绳而用之, 甘其 食, 美其服, 安其居, 乐其俗。邻国相望, 鸡犬之声相闻, 民至老死, 不相往来。cf. also (Feng and English 1997), c. 80. For an evolutionary reading, cf. (Schönfeld 2013, 2014).
} 
leap, but this leap is also natural, since Daoism merely suggests that the time has come for humans to grow up.

\section{Aspiring to an Ecological Civilization}

Politics matters for environmental activism because civil liberties, such as freedom of expression and freedom of assembly, cannot be taken for granted. China's political system puts collective welfare first. At the same time, the destabilization of the Earth System, the prospect of the hothouse trajectory, and the U.N. warning that civilization has only ten years left to step back from the cliff, raises the question of whether civilization can continue afford prioritizing civil liberties over collective welfare. Governance in liberal democracies, as in USA, Australia, and Brazil, has fallen prey to regulatory capture by fossil fuel companies. Western legal systems give protection to climate deniers, science skeptics, and market libertarians, who disseminate misinformation and lobby elected officials with impunity. As a result, the West is in disarray over the crisis, with the U.S., Australia, and Brazil on one side, and the EU-27 and Norway on another. Overlooked by the Western critique of China's suppression of free speech is that internet regulations such as the "Seven Baselines" (qitiao dixian 七 条底线) include the requirement of information accuracy. Compelling its citizens and its officials to stick to environmental facts—and punish them when they do not-has given China a strategic edge over the market-driven and post-truth dissolution that hamstrings Western aspirations to save the planet. While U.S. officials are free to dismiss global warming as a "niche interest" (as at the 2019 G-7 meeting), the People's Republic of China has taken the lead to try saving at least its own citizens from the perils of the climate emergency.

A key difference to the post-truth politics in liberal democracies emerged during the 16th Central Committee of the CP China 2002-2007. Then General Secretary and President Hu proposed the concept of the “Scientific Outlook on Development" (科学发展观, kexue fazhan guan). It was ratified in China's constitution in 2007 and has become one of the pillars of Xi Jinping Thought. The Scientific Outlook concept means various things, but its core idea is that socialist policy, unlike liberal policy, is based on a fundamental respect for science. The consensus on planetary boundary crossings accordingly means that the Scientific Outlook is to be implemented in reality-based, low-carbon, and sustainable development.

Combining Scientific Development with Ecological Civilization evokes the prospect of civil evolution outlined by Daoism. Liberal democracies entered the climate crisis with highly developed infrastructure and strong environmental regulations but then punted. Green leaders of the Western world, such as the Merkel administration of Germany, have made so many concessions to private interests that its pioneering solar- and wind-industries have been faltering, and that its national carbon emissions are at risk of missing reduction targets for $2020 .{ }^{36}$ China, by contrast, entered the crisis with a poor infrastructure, little in terms of environmental regulations, and with a natural environment in far worse shape than that of any Western nation. Compared to liberal democracies, China had a lot farther to go. And yet, the speed of its transition to sustainability outpaces what the West has to show for itself (Wang et al. 2019). ${ }^{37}$ It is therefore no exaggeration to state that, "Environmental protection has become a global consensus, but the Communist Party of China is the first to take on ecological construction as an action platform of a political party, especially a ruling party" (Hsiung et al. 2015). ${ }^{38}$

The speed is born of necessity. After the fall of Communism outside China, Deng Xiaoping concluded that "only rapid economic growth would maintain the public support necessary to avoid

\footnotetext{
(Uken 2019; Schultz 2019; Haffert 2019).

37 At the Paris Climate Accord 2015, the Xi government had pledged to reduce its $\mathrm{CO}_{2}$ emissions output starting in 2030. Calculations released in 2019 indicate the China's emissions will decline ten years sooner, peaking in 2019 and start declining in 2020. cf. (Wang et al. 2019).

38 (Hsiung et al. 2015, p. 287).
} 
the fate of Eastern Europe and the Soviet Union" (Vogel 2011). ${ }^{39}$ Deng doubted that Mao's vision of cityscapes dominated by "chimneys everywhere" would be the way to go (Chang and Halliday 2005). ${ }^{40}$ He set the course for his successors on his 'southern journey,' the 1992 visit to the Shenzhen Special Economic Zone (SEZ) established in 1980, where he suggested a different type of development-urban instead of rural, high-tech instead of industrial, and clean instead of toxic. Deng's final political gesture was to exhort Shenzhen-style development as blueprint for China's future. ${ }^{41}$ Jiang Zemin implemented Deng's strategy: maintaining the government's legitimacy will require boosting development, but not at the expense of the environment. Jiang inherited Deng's problem of how to restore popular support for Communist rule. As a step towards a solution, he decreed the doctrine of the 'Three Represents' (sange daibiao 三个代表): The Party must represent economic progress, political consensus, and cultural development (Jiang 2013). ${ }^{42}$ 'Economic progress' means clean development. 'Political consensus' means the admission that political power does not grow out of the barrel of a gun, as Mao said in 1927, but comes from popular support. 'Cultural development' means to ground national identity in China's history and to reconcile political ideology with traditions, including Daoism.

$\mathrm{X}_{\mathrm{i}}$ Jinping took the helm as General Secretary when high-tech development was still more of a promise than reality, and when the economic boom of the previous decades had led to severe degradation of soil and water. Urban air pollution had become so bad that health concerns fomented a new surge of public discontent. Party officials acknowledged that "the environment had surpassed illegal land expropriation as the largest source of social unrest in the country" (Economy 2018). ${ }^{43}$ By seeking to balance development with the environment, $\mathrm{Xi}$ is facing the "most severe test of his time- to alleviate the economy's pressure on China's resources," a test that he approaches by harnessing China's traditions, so as to ground sustainable development in "eastern wisdom" (Hsiung et al. 2015). ${ }^{44}$

In practice, the government addresses these concerns on the technological level, by installing a nationwide network of environmental monitoring stations; on the legal level, by broadening existing environmental regulations; and on the political level, by conducting anti-corruption campaigns. It is one thing to have good data and strong laws, but quite another to convince party officials to enforce the laws instead of being lobbied by a donor class of polluters. On the ideological level, Xi took up Hu's 2007 call for constructing an Ecological Civilization (shengtai wenming). In 2012, at the 18th National Congress, the Party amended its constitution by adding the construction of an Ecological Civilization as a major goal, and part of the "five in one" endeavor (wuwei yiti 五位一体). ${ }^{45}$

Upon assuming power in 2013, Xi declared that strengthening environmental protection is an indispensable part of realizing the "Chinese Dream of National Rejuvenation" (zhongguo meng 中国 梦). ${ }^{46}$ Xi introduced the concept of “Ecological Red Lines" (shengtai hong xian 生態紅线) and sharpened Jiang's idea of balancing economic growth and environmental protection into a double equation: "protecting the environment equals to protecting productivity, and improving the environment also equates to developing productivity" ( $\left.\mathrm{Xi}_{\mathrm{i}} 2014\right) .{ }^{47} \mathrm{In}$ the same year, he gave unprecedented political weight to the concept of "future generations" (hou dai 後代) by decreeing that China will “leave to our future generations a working and living environment of blue skies, green fields and clean water." In the same letter, $\mathrm{Xi}$ identified "addressing climate change" as a "common challenge for the whole

39 (Vogel 2011, p. 659).

40 On the subject of modernization, Mao Zedong once said, "Looking out from Tiananmen, I should see chimneys everywhere"; cf. (Quan 2017); see also (Chang and Halliday 2005, p. 510).

41 (Vogel 2011, pp. 673-75).

42 Z.-M. Jiang, "Better effectuate the Three Represents under the new historical conditions (February 2000)" in (Jiang 2013, vol. 3, pp. 1-2).

43 (Economy 2018, p. 160).

44 (Hsiung et al. 2015, p. 251).

45 Prior to the 18th Nat'l Congress, the Party Constitution consisted of sections on four realms ("four in one"): economic, political, cultural and social construction. Ecological Civilization adds a fifth realm.

46 "A better environment for a beautiful China," speech given Apr 2, 2013, in (Xi 2014, p. 229).

47 "Usher in a new era of ecological progress," speech given May 24, 2013, in (Xi 2014, p. 231). 
world" and promised that China will work with other countries to "make the earth an environmentally sound homeland" (Xi 2014). ${ }^{48}$ In 2015, the concept of "green development" (lïse fazhan 绿色发展) was put forward at the 5th Plenary Session of the 18th Central Committee of the CP China as part of the 13th Five Year Plan for 2016-2020.

Parallel to his push of Chinese socialism towards environmentalism, General Secretary Xi Jinping acknowledges the importance of philosophical and spiritual traditions for the development of Chinese socialism for the new era. At a talk in 2014, Xi characterized Daoism as "natural" (ziran 自然), stated that Daoism deeply affects the lives of Chinese people, and appealed to Laozi. At another talk, in 2015, in the context of protecting water as a resource, he quoted verbatim from the Daodejing. ${ }^{49}$ Attending the 2016 National Workshop on Religion, Xi said that religious activities need to be adapted to the socialist society and added that these activities will help to bring about the desired "Sinification of religion" (zongjiao de zhongguo hua fangxiang 宗教的中国化方向). Accordingly adapted to ideological goals and adopted by policy makers, Daoism is a resource for constructing an Ecological Civilization as the next stage of socialism.

Reflecting the urgency of the planetary crisis, Xi has struck a sharper tone in recent years. In 2016, he warned that "it is high time we intensified eco-environmental protection" because ecological destruction affects sustainable development (Xi 2017). ${ }^{50}$ Later that year, he urged to "speed up China's development in a green, circular [closed-loop], and low-carbon fashion" and stated that "emphasis will be put on the supervision of environmental crimes and violations of Party discipline". ${ }^{51}$ In 2017, he decreed that the "model based on an increase in material resource consumption, extensive development, high energy consumption, and high emissions" must be abandoned; "comprehensive control of environmental pollution" must be intensified; environmental restoration must happen quicker, and the wish for a happy life for the people must be balanced against the needs of future generations. For constructing an Ecological Civilization, "it is imperative to have the strictest possible institutions and legislation in place" (Xi 2017). ${ }^{52}$

\section{Environmental Activism and Case Studies}

The Chinese Daoist Association (CDA) advocates a frugal, anti-consumerist, and health-oriented lifestyle cognizant of environmental and climate needs. Daoist practitioners promote environmental protection, energy conservation, waste separation and recycling, and low-carbon technologies. At the turn of the millennium, and in collaboration with the World Wildlife Fund, the Shaanxi Daoist community launched a project called "Creating Environmental Temples" (huanjing youhaoxing daojiao gongguan 环境友好型道教宫观), which led to the building of the Tiejia Ecology Temple at Mt. Taibai in the Qinling mountains in Shaanxi province in northwest China (Lemche and Miller 2019). ${ }^{53}$ This was a pilot project of sustainable design for religious buildings. The initiative subsequently spread from Shaanxi through China. A follow-up declaration by the CDA, in 2014, expands the Environmental-Temple initiative from architecture to worship, and from building design to temple activities. The burning of incense-sticks, for instance, is a ritual of prayer, but the CDA now recommends, while not doing away with incense burning altogether, to keep it at a minimum. In 2015, the Xi Jinping administration endorsed the Environmental-Temple initiative through the National Bureau for Religious Affairs, which issued a statement that houses of worship henceforth need to be constructed according to the sustainable standards set at Shaanxi.

\footnotetext{
48 “Leave to our future generations blue skies, green fields and clean water," open letter, 18 Jul 2013, in (Xi 2014, pp. 233-34).

49 In a speech in November 2014, Xi quoted “the highest good is like water" (上善若水) from Daodejing c. 8.

"Eco-environmental protection is an integral component of development," speech, 24 Aug 2016, in (Xi 2017, p. 425).

1 "Clear waters and green mountains are invaluable assets," comments, 28 Nov 2016, in (Xi 2017, p. 426).

52 "Green development model and green way of life," speech, 26 May 2017, in (Xi 2017, pp. 428-31). Note that the official translation of Xi's phrase jianshe shengtai wenming is not the literal "construction of an ecological civilization" but a more circumspect phrase, "ushering in ecological progress." Cf. also (Xi 2018, p. 205), and compare (Xi 2018, p. 205).

53 For a description of the Tiejia Ecology Temple, cf. (Lemche and Miller 2019).
} 
The Shaanxi project also serves as a symbolic gesture to put the ancient environmental values of Daoism front and center for the new millennium. Starting in 2006, the CDA convened national symposia on Ecological Education (zhongguo daojiao shengtai jiaoyu zuotan hui 中国道教生态教育座谈会). These symposia led to proclamations such as the 2006 Qinling Declaration (秦岭宣言), the 2008 Maoshan Declaration (茅山宣言), and the 2014 Ziyang Declaration (紫阳宣言). Together, they define Daoist environmentalism by way of their suggestions: a Daoist ought to maintain a small carbon footprint, use mass transit, oppose consumerism, cherish resources, and care for the environment. "Caring for the environment" (aihu huanjing 爱护环境) means to protect rare plants and wild animals—Daoists are not supposed to pick wildflowers, and neither are they to connect to nature by sports hunting. In line with the described lack of distinctions (a lack that yields to a conceptual continuum of nature and humans, specifically to a continuum from the environment to the body), Daoist environmentalism is also practiced by clean living, body cultivation, and health care methods such as Traditional Chinese Medicine (TCM)..$^{54}$

Similar to the Chinese government, which bundles its policies in development initiatives known as Five Year Plans, the CDA bundles its initiatives in Seven (or Eight) Year Plans. ${ }^{55}$ The 2019-2025 CDA Seven Year Plan for Environmental Protection (zhongguo daojiao jiehui huanjing baohu qinian guihua 中国道教界会环境保护七年规划) features ecological education, conservationism, and wildlife protection. Some of the items are specific to Chinese culture. For example, the rubric "wildlife protection" (yeshengdong wubaohu 野生动物保护) of the Seven Year Plan prohibits physicians and clinics specialized in Traditional Chinese Medicine (TCM) from using plants and animals that are on China's endangered species list. Other items are cross-cultural if not universal demands. In the rubric "ecological education" (shengtai jiaoyu 生态教育), the CDA asks practitioners to reduce and recycle waste, and to save water and energy. Yet other recommendations in the Seven Year Plan reflect the planetary transformation. Thus, practitioners are asked to adopt low-carbon temple management, lifestyle, and travel; avoid fossil fuels whenever possible, and promote the use of renewable energy in their households and communities. Topping the list in the rubric "conservationism" (shengai baohu hehuan jingbaohu 生态保护和环境保护) is the demand for active participation in the mitigation of climate change, in the individual reduction of carbon emissions, and in tree-planting initiatives. The language also reflects the changing times, for the CDA's demand is not merely for "planting trees" but explicitly also for "expanding forest carbon sinks". ${ }^{56}$

These demands in the 2019-2025 CDA Plan are grounded in a series of regional projects of environmental activism from 2003 to the present. The recommendation of planting trees is implemented in a Daoist-run project in the remote northwest of China. In 2003, the CDA established an "Ecological Reforestation Base" (shengtai linjian shejidi 生态林建设基地) in Minqin county in Gansu province. Gansu is the beginning of the Silk Road; it is bounded by mountains in the west and the Gobi in the east. The Gobi Desert is expanding, and airborne sand impairs agriculture to the east, and it has led to a so-called fifth season, a dust season between spring and summer, in faraway Beijing. Climate change is predicted to make the Gobi Desert even larger. Minqin is at the frontline in the fight against desertification. The desert can be hemmed in by planting hardy shrub- and tree species at its edges. The Ecological Reforestation Base is part of this regional endeavor. The Daoist afforestation project is sustained by grassroot support, volunteer work, and private donations to purchase seedlings. The project has garnered sufficient private donations from practitioners to halt the march of the desert at least in this corner of the province.

54 For an account of the 'greening' of the CDA from 1995 to 2008, with further information on the Qinling and Maoshan declarations; cf. (Lemche and Miller 2019), sect. 2.

55 The "plans" (guihua, 規劃/规划) of the CDA are an emerging structure. The 2019-2025 CDA Seven Year Plan for Environmental Protection is the first of its kind and was preceded by a proposed draft (gangyao yijian 纲要意见) of the 2010-2017 CDA Eight Year Plan for Environmental Protection (zhongguo daojiaojie baohu huanjing de banian guihua 中国道教界保护环境的八年规划).

56 The choice of words reflects the planetary transformation. The traditional precept, to plant trees (zhi shu 植树), is supplemented in the 2019-2025 Plan by the demand of “increase forest carbon sinks" (zengjia senlin tanhui 增加森林碳汇). 
In 2009, in Jiangxi province in southeastern China, the State Council approved a development project that the provincial government had applied for and whose design is based on Daoist ideas. This is the Lake Poyang eco-economic planning zone at Poyang Lake, which is the largest freshwater lake in China. It is the first regional development plan in the province that has risen to a national strategic level. The plan implements the Daoist ideas of the human-nature continuum and of the treasure of frugality. The human-nature continuum, in this context, is the aspiration to align development with the ideal of "unity of heaven and humanity and coexistence of all things" (tianren he yi; wanwu gongcun 天人合一; 万物共存). Frugality or jian, one of the three treasures or core values, translates here into the development principle of “knowing contentment" (zhi zhi, zhi zu 知止知足). Poyang Lake is connected to the Yangtze river downstream from the Three Gorges Dam. Because of the dam regulating river flow, lake levels have fluctuated dramatically, which has degraded the ecosystem and led to a loss of wildlife. The lake is home to an endangered porpoise, which is at risk of following the Yangtze river dolphin into extinction. Daoist activists at Poyang Lake organized to fight for conservationist measures to allow the freshwater ecosystem to regenerate and the last Chinese dolphin species to survive.

The Jiangxi provincial government aids the activists by channeling industrial development in the lake region into a more sustainable direction: in the manufacturing sector, from low-tech to high-tech and service industries, and in the energy sector, from coal-burning plants to an energy basket of nuclear power, hydroelectric power, and wind turbines. The Daoist-inspired development project was approved as a measure to stabilize Lake Poyang, to protect the provincial environment, and to do Jiangxi's part in fighting climate change. Provincial Governor Wu Xinxiong 吴新雄 puts the Lake Poyang project in the context of climate mitigation with four stated goals: afforestation, water resource management, sewage/garbage treatment, and wilderness protection.

Next to the afforestation project in Gansu and the conservationist project in Jiangxi, the CDA seeks to combine activism with education. It does so by creating green zones that are a mixture of educational theme parks, environmental sanctuaries, and eco-tourist destinations. One such example is in Shaanxi province. This is the "Six Rivers and Six Belts" (liu he liu dai 六河六带) zone in Zhouzhi county, which was in the planning stage in 2018 and is now under construction. Zhouzhi is a large and sparsely populated county, consisting of mountainous bamboo forests that are home to the Giant Panda. Daoist activists persuaded the Shaanxi provincial government to combine existing wilderness preserves (the Zhouzhi nature reserve and the Cuifeng mountain forest park) with rewilding corridors into a large sanctuary that would protect two-thirds of the county's area. Again, in line with Daoist aesthetics and ethics, the design of the rewilding corridors seeks to reconcile existing infrastructure with ecological hotspots that would protect the forest belts and river valleys, allow biodiversity to flourish, and afford educational opportunities to visitors. The "Six Rivers and Six Belts" project is a joint venture of the Shaanxi provincial government and the Louguantai 楼观台 Daoist temple.

The combination of wilderness protection and environmental education reflects a larger goal of Daoism, the reconciliation of nature and culture, or of environmental and societal needs, through the creation of healthy landscapes. This can take the form of ecotourist destinations, as in the Panda habitats of Shaanxi, but it also assumes more mundane forms, such as the development of ecofriendly residential zones, and the creation of organic farms. Examples of green residential developments are in Sichuan province in southwest China, and in Hunan province in central China. In Sichuan, the CDA has been developing in 2018 and 2019 a green residential zone in the capital, Chengdu, the "Daoyuan Shengcheng Environmental Health villa" (daoyuan shengcheng zhuti shengtai yangsheng bieshuxiangmu) (道源圣城主题生态养生别墅项目). It surrounds a cultural landmark, Mt. Heming, which is the historical birthplace of Daoism. It is aimed at upscale residents who want to escape city life to a sustainable exurban community. Another of such ongoing projects, in Hunan province, is a green residential zone in Hunan's capital Changsha. This is the "Canlong Binhu International Area" (canlong binhu guoji shequ 藏珑滨湖国际社区). The design of this green development zone reflects the Daoist ideal of living naturally, or being close to nature, by combining ecosanctuaries with high-density urban living. An example of an organic farming project is in Zhejiang, a coastal province 
south of Shanghai. This is the "Natural Agricultural Eco-Village" (ziran nongfa shengtai cun 自然农 法生态村) at the "Lake of Thousand Islands" or Lake Qiandao, which is an artificial lake covering several hundred square kilometers in a large forest. The Daoist practitioners who run it say that this farming community "uses the wisdom of the Daodejing to practice natural farming as harmony of nature and humans". The Eco-Village is being promoted by Zhejiang entrepreneurs and run by Daoist practitioners. It serves as a showcase for sustainable farming according to Daoist principles and has received nationwide recognition.

In sum, Daoism, certainly among the greenest of all religions, is rising to the challenges of the planetary transformation. Its spiritual narrative, which concerns a continuum between nature and humans, can seamlessly integrate the sea change of the early Anthropocene, which is marked by planetary boundary crossings and which ties to fate of human wellbeing to Earth System integrity. Environmental activism in the Daoist community benefits from the ideological transformation of post-Maoist China, which makes the construction of an Ecological Civilization a priority for Socialism with Chinese Characteristics in the New Era. General Secretary Xi Jinping recognizes the gravity of the planetary crisis and the urgency of sustainable development. His administration utilizes the structural realities created by his predecessors, specifically the rise of non-state actors, by harnessing the activities of Daoist practitioners towards shared ecological goals. This alignment of Daoism and Communism is facilitated by science. Daoism anticipates in its ancient ontology core elements of the Scientific Standard Model, especially over ecology and evolution. Daoist practitioners are comfortable with scientific findings and integrate them in their teachings. Marxism-Leninism received a key update through Xi's predecessor Hu Jintao with his concept of the Scientific Outlook on Development. This ideological update commits the Communist Party to pursue policies oriented on sustainable development and on scientific findings. The fruit of this Daoist-Communist alignment is a roster of environmental projects across China, ranging from afforestation to rewilding to conservation to green development to sustainable agriculture. Common to all of them is that they started as grassroots initiatives by environmental activists and were encouraged and supported by the government on local, provincial, and national levels. This lets us end our examination of Daoist environmentalism vis-à-vis the project of an Ecological Civilization on a hopeful note. Spirituality, socialism, and science constitute a future-oriented combination of cultural resources in China, which gives us a very real chance of avoiding the hothouse fate.

Author Contributions: M.S. wrote the article in English, and X.C. provided materials in Chinese. Section 1 (Introduction) and Section 2 (Shifting Conceptions ... ) are based on Schönfeld's research. Section 3 (Daoist Environmentalism) and Section 4 (Ecological Civilization) are based on Chen's and Schönfeld's joint research. Section 5 (Environmental Activism) is based on Chen's research.

Funding: This research received no external funding.

Conflicts of Interest: The authors declare no conflict of interest.

\section{References}

Ayres, E. 2000. The four spikes. Futures 32: 539-54. [CrossRef]

Bar-On, Y. M., R. Phillips, and R. Milo. 2018. The biomass distribution on Earth. Proc. Natl. Acad. Sci. USA 115: 6506-11. [CrossRef] [PubMed]

Bevis, M., C. Harig, A. K. Shfaqat, A. Brown, S. J. Frederik, M. Willis, X. Fettweis, M. van den Broeke, F. B. Madsen, E. Kendrick, and et al. 2019. Accelerating changes in ice mass within Greenland, and the ice sheet's sensitivity to atmospheric forcing. Proc. Natl. Acad. Sci. USA 116: 1924-39. [CrossRef] [PubMed]

Box, J. 2019. Tweet (31 July): On the NW Greenland Ice Sheet, 2019 Melt to-Date is 1.2x That of the Previous Record Melt in 2012. Available online: https://twitter.com/climate_ice/status/1156568949129170944 (accessed on 15 August 2019).

British Petroleum. 2019. BP Statistical Review of World Energy 2019, 68th ed. London: Pureprint, 64p. 
Ceballos, G., P. Ehrlich, and R. Dirzo. 2017. Biological annihilation via the ongoing Sixth Mass Extinction signaled by vertebrate population losses and declines. Proc. Natl. Acad. Sci. USA 114: E6089-E6096. [CrossRef] [PubMed]

Chan, W.-T. 1963. A Sourcebook in Chinese Philosophy. Princeton: Princeton University Press.

Chang, J., and J. Halliday. 2005. Mao: The Unknown Story. New York: Anchor, p. 510.

Chen, X., and M. Schönfeld. 2013. A Daoist response to climate change. In Global Ethics on Climate Change: The Planetary Crisis and Philosophical Alternatives. Edited by M. Schönfeld. London: Routledge, pp. 67-75.

Díaz, S., J. Settele, E. Brondizio, H. T. Ngo, M. Gueze, J. Agard, A. Arneth, P. Balvanera, K. Bauman, S. Butchart, and et al. 2019. Summary for Policymakers. In Science-Policy Platform on Biodiversity and Ecosystem Services (IPBES), Global Assessment Report on Biodiversity and Ecosystem Services. Geneva: UNEP/UNESCO/UNFAO and UNDP.

Dirzo, R., H. Young, M. Galetti, G. Ceballos, N. Isaac, and B. Collen. 2014. Defaunation in the Anthropocene. Science 345: 401-6. [CrossRef] [PubMed]

Economy, E. C. 2018. The Third Revolution: Xi Jinping and the New Chinese State. New York and Oxford: Oxford University Press.

Engelsdorp, D., R. van Underwood, D. Caron, and J. Hayes. 2007. An estimate of managed colony losses in the winter of 2006-2007. American Bee Journal 14: 599-603.

Engelsdorp, D., J. van Hayes Jr., R. Underwood, and J. Pettis. 2008. A survey of honey bee colony losses in the U.S., fall 2007 to spring 2008. PLoS ONE 3: e4071. [CrossRef]

Translated and Edited by G.-F. Feng, and J. English. 1997, Lao Tzu Tao Te Ching. New York: Vintage.

Fettweis, X. 2019. Tweet (31 July): The Last MAR Forecast Suggests That the Ablation Rate of 1 Aug (SMB -12.5 GT/Day) Could Be the Higest in the Greenland History ... Such Daily SMB Rate Corresponds to What MAR Projects for 2070 Using SSP585. Available online: https://witter.com/xavierfettweis/status/ 1156487868950482945 (accessed on 15 August 2019).

Fettweis, X., B. Franco, M. Tedesco, J. van Angelen, J. Lenaerts, M. van den Broeke, and H. Gallee. 2013. Estimating the Greenland ice sheet surface mass balance contribution to future sea level rise using the regional atmospheric climate model MAR. The Cryosphere 7: 469-89. [CrossRef]

Fletcher, C. 2019. Climate Change: What the Science Tells Us. Hoboken: Wiley.

Foster, J. 1999. Marx's theory of metabolic rift: classical foundations for environmental sociology. American Journal of Sociology 102: 366-405. [CrossRef]

Grooten, M., and R. Almond, eds. 2018. Living Planet Report 2018: Aiming Higher. Gland: WWF.

Haffert, C. 2019. Zweite Chance für Solarzellen 'made in Germany'. Der Spiegel, August 13.

Hallmann, C., M. Sorg, E. Jongejans, H. Siepel, N. Hofland, H. Schwan, W. Stenmans, A. Mueller, H. Sumser, T. Hoerren, and et al. 2017. More than 75 percent decline over 27 years in total flying insect biomass in protected areas. PLoS ONE 12: e0185809. [CrossRef] [PubMed]

Hayhoe, K., J. Edmonds, R. Kopp, A. LeGrande, B. Sanderson, M. Wehner, and D. Wuebbles. 2017. Climate models, scenarios, and projections. In Climate Science Special Report: Fourth National Climate Assessment. Edited by D. Wuebbles, D. Fahey, K. Hibbard, D. Dokken, B. Steard and T. Maycock. Washington, DC: US Global Change Res. Program, vol. 1, pp. 133-60. [CrossRef]

Holthaus, E. 2019. Greenland is melting away before our eyes. Rolling Stone, July 31.

Hsiung, J., H. Liu, Y. Chen, X.-W. Zhou, and H.-S. Tan. 2015. The Xi Jinping Era: Comprehensive Strategy toward the China Dream. Beijing and New York: CN Times Books, p. 287.

Intergovernmental Panel on Climate Change (IPCC). 2018. Global Warming of $1.5^{\circ} \mathrm{C}$ : An IPCC Special Report on the Impacts of Global Warming Above Pre-Industrial Levels and Related Global Greenhouse Gas Emission Pathways, in the Context of Strengthening the Global Response to the Threat of Climate Change, Sustainable Development, and Efforts to Eradicate Poverty. Geneva: WMO/UNEP.

Intergovernmental Panel on Climate Change (IPCC). 2019. Climate Change and Land: An IPCC Special Report on Climate Change, Desertification, Land Degradation, Sustainable Land Management, Food Security, and Greenhouse Gas Fluxes in Terrestrial Ecosystems. Geneva: UNEP/WMO. Available online: https://www.ipcc.ch/report/srccl/ (accessed on 15 August 2019).

Jarvis, B. 2018. The insect apocalypse is here-What does it mean for the rest of life on Earth? New York Times, November 27, 16p.

Jiang, Z.-M. 2013. Selected Works of Jiang Zemin. 3 vols. Beijing: Foreign Language Press. 
Kohn, L. 2014. Zhuangzi: Text and Context. St. Petersburg: Three Pines Press.

Lemche, J., and J. Miller. 2019. Global capital, local conservation, and ecological civilization: The Tiejia Ecology Temple and the Chinese Daoist Association's green agenda. Religions 10: 580. [CrossRef]

Linden, E. 2019. How scientists got climate change so wrong: few thought it would arrive so quickly. Now we're facing consequences once viewed as fringe scenarios. New York Times, November 11.

McKie, R. 2019. We must change food production to save the world, says leaked report. The Guardian, August 4.

Miller, J. 2017. China's Green Religion: Daoism and the Quest for a Sustainable Future. New York: Columbia University Press.

Moeller, H. G. 2006. The Philosophy of the Daodejing. New York: Columbia University Press.

Moeller, H.G. 2015. Basic aspects of Daoist philosophy. International Communication of Chinese Culture 2: 99-107. [CrossRef]

Neilson, S. 2019. More Bad Buzz for Bees: Record Number of Honeybee Colonies Died Last Winter. NPR [National Public Radio, USA], June 19.

Milman, O. 2019. U.S. Beekeepers Lost 40\% of Honeybee Colonies over Past Year. The Guardian. June 19 U.S. Data at the Bee Informed Partnership (U Maryland). Available online: https://beeinformed.org/ (accessed on 15 August 2019).

Perkins, F. 2004. Leibniz and China: A Commerce in Light. Cambridge: Cambridge University Press.

Quan, Y. 2017. Controversial chimney stokes industrial heritage debate. China Daily, August 30.

Schönfeld, M. 2013. The endpoint of civil evolution. Daodejing c. 80 and climate philosophy. Journal of Religious Philosophy [宗教哲學期刊] 63: 39-53. (In Chinese).

Schönfeld, M. 2014. The Dao of geo-engineering: wuwei of environmental intervention. Journal of Religious Philosophy [宗教哲學期刊] 64: 97-112. (In Chinese).

Schultz, S. 2019. Die grosse Windkraftkrise. Der Spiege, August 1.

Steffen, W., K. Richardson, J. Rockström, S. Cornell, I. Fetzer, E. Bennett, R. Biggs, S. Carpenter, W. de Vries, C. de Wit, and et al. 2015. Planetary Boundaries: Guiding human development on a changing planet. Science 347. [CrossRef] [PubMed]

Steffen, W., J. Rockström, K. Richardson, T. Lenton, C. Folke, D. Liverman, C. Summerhayes, A. Barnosky, S. Cornell, M. Crucifix, and et al. 2018. Trajectories of the Earth System in the Anthropocene. Proc. Natl. Acad. Sci. USA 115: 8252-59. [CrossRef] [PubMed]

Uken, M. 2019. Der Totalausfall. Die Zeit, August 30.

Vogel, E. 2011. Deng Xiaoping and the Transformation of China. Cambridge and London: Harvard University Press. Vogel, G. 2017. Where have all the insects gone? Surveys point to a dramatic decline in insect biomass. Key members of the ecosystem may be slipping away. Science 356: 576-79. [CrossRef]

Wackernagel, M., N. Schulz, D. Deumling, Callejas A. Linares, M. Jenkins, V. Kapos, C. Monfreda, J. Loh, N. Myers, R. Norgaard, and et al. 2002. Tracking the ecological overshoot of the human economy. Proc. Natl. Acad. Sci. USA 99: 9266-71. [CrossRef]

Wang, H.-K., X. Lu, Y. Deng, Y.-G. Sun, C. Nielsen, Y.-F. Liu, G. Zhu, M.-L. Bu, J. Bi, and M. McElroy. 2019. China's $\mathrm{CO}_{2}$ peak before 2030 implied from characteristics and growth of cities. Nature Sustainability 2: 748-54. [CrossRef]

Xi, Jinping. 2014. On Governance. Beijing: Foreign Language Press, vol. 1.

Xi, Jinping. 2017. On Governance. Beijing: Foreign Language Press, vol. 2.

Xi, Jinping. 2018. Tan Zhi Guoli Zheng. Beijing: Waiwen Chuban.

Zhuangzi. 1994. Wandering on the Way: Early Taoist Tales and Parables of Chuang Tzu. Translated by V. H. Mair. Honolulu: University of Hawaii Press.

(C) 2019 by the authors. Licensee MDPI, Basel, Switzerland. This article is an open access article distributed under the terms and conditions of the Creative Commons Attribution (CC BY) license (http://creativecommons.org/licenses/by/4.0/). 